\title{
Knowledge of Covid-19 among Medical Scientists in Nigeria
}

\author{
Lekan-Agunbiade Titilayo Tosin ${ }^{*}$, Agunbiade Olalekan Isaiah ${ }^{2}$, \\ Omosebi Funmi Ayomide3, Ogundare Stephen Olusegun ${ }^{4}$
}

${ }^{1}$ Microbiology Laboratory, Midland Regional Hospital, Portlaoise, Ireland

${ }^{2}$ Intensive Care Unit. Midland Regional Hospital, Portlaoise, Ireland

${ }^{3}$ Lagos State Health Service Commission, Isolo General Hospital Ikeja, Nigeria

${ }^{4}$ Olabisi Onabanjo University Teaching Hospital, Ogun State, Nigeria

Email: *titilayolekanagunbaide@gmail.com, oluomolekiaguns@yahoo.com,

funmiakintilo4@gmail.com,ogundareolusegun@gmail.com

How to cite this paper: Tosin, L.-A.T., Isaiah, A.O., Ayomide, O.F. and Olusegun, O.S. (2021) Knowledge of Covid-19 among Medical Scientists in Nigeria. Journal of Biosciences and Medicines, 9, 11-25. https://doi.org/10.4236/jbm.2021.96002

Received: April 25, 2021

Accepted: June 1, 2021

Published: June 4, 2021

Copyright $\odot 2021$ by author(s) and Scientific Research Publishing Inc. This work is licensed under the Creative Commons Attribution International License (CC BY 4.0).

http://creativecommons.org/licenses/by/4.0/

\begin{abstract}
Background: The impacts of the ongoing COVID-19 pandemic have created a need for constant improvement in the effectiveness and efficiency of laboratory diagnosis to contain the spread, aid the treatment and management of positive cases. Inadequate knowledge of COVD-19 and its laboratory diagnosis among medical scientists is detrimental to the reliability of laboratory results, which are critical in the control, and management of the COVID-19 pandemic. The purposes of this study are to determine the knowledge of COVD-19 and to assess the knowledge of laboratory diagnosis of SARS-CoV-2 among medical scientists. Methodology: An internet-broadcasted and validated questionnaire was used to obtain data from 131 medical scientists in Nigeria. The generated data were analyzed using IBM SPSS Statistics version 25. Results: More than half of respondents had good general knowledge and causes (52\%), mode of transmission (52.7\%), and symptoms (54.2\%) of COVID-19. However, only a few $(<40 \%)$ knew the hallmark of laboratory diagnosis of COVID-19 and Coronavirus detection steps in the right order (45\%). Surprisingly, age (F-ratio $=2.729 \mathrm{p}=0.032)$, gender $\left(\chi^{2}=4.173 ; \mathrm{p}=0.041\right)$ and level at work (F-ratio $=3.552, \mathrm{p}=0.016)$ have significant effects on the knowledge of COVID-19 and knowledge of laboratory diagnosis of SARS-CoV-2 among the study participants. Conclusion: There is a need for improvement in the knowledge of COVID-19 diagnosis through relevant work level (work experience) and gender-based training as well as continuous professional development programs for medical scientists in Nigeria.
\end{abstract}

\section{Keywords}

COVID-19, Coronavirus Disease, Knowledge, Laboratory Diagnosis, 


\section{Background}

Six weeks after the first reported case of the novel Coronavirus infection in $\mathrm{Wu}$ han, China, Africa continent recorded her first case in Egypt [1]. On $27^{\text {th }}$ February 2020, which was, almost two weeks after it was reported in Egypt, Nigeria recorded her first COVID-19 case [2]. In this unprecedented time in the world's history, the COVID-19 test has become a household vocabulary. This is because COVID-19 testing is the fundamental core of COVID-19 pandemic response to contain the spread of Coronavirus infection. Medical scientists play a pivotal role in the diagnosis of COVID-19, monitoring of patients that are positive for SARS-CoV-2 infection, and epidemiologic surveillance. The relevance of laboratory results and the constant demand to increase testing have place medical scientists in the spotlight in the management of the COVID-19 crisis all over the world.

It was discovered that the incubation period of SAR-CoV-2 is 14 days [3], while the mode of transmission is through physical contact, droplets, aerosol, and contaminated environments [4] [5].

The symptoms of COVID-19 infection ranges from an asymptomatic form to a severe acute respiratory syndrome-a severe complication of SAR-CoV-2, which could lead to viral sepsis, disseminated intravascular coagulopathy (DIC), or multiple organ failure (MOF). However, common symptoms include dry cough, fever, and fatigue [6] [7].

Early laboratory diagnosis of COVID-19 plays a major role in the control and management of the COVID-19 pandemic. The laboratory confirmation of suspected cases of COVID-19 is done using Nucleic Acid Amplification tests (NAAT) which detect the unique viral RNA sequences. A major example of NAAT is real-time reverse transcription polymerase chain reaction (RT-PCR) and the most widely used type is quantitative fluorescence-based reverse transcription polymerase chain reaction (RT-qPCR). The common targeted viral genes are N, E, S, and RdRP [8]. RT-PCR detects SARS-CoV-2 during the acute phase of infection.

RT-PCR involves the extraction of viral genomic RNA, conversion of the RNA into complementary DNA (cDNA) by RNA-dependent DNA polymerase (reverse transcriptase)-the binding of primers to the DNA provides a template for DNA replication by DNA polymerase enzyme, leading to degradation of the bound probe which generates fluorescence signal. Fluorescence signal increases as more copies of DNA are produced. In quantitative fluorescence-based reverse transcription polymerase chain reaction (RT-qPCR), real-time monitoring of DNA amplification is monitored using fluorescent dye or a sequence-specific DNA probe labeled with a fluorescent molecule (reporter molecule) and a 
quencher molecule. As the PCR reaction progresses, the amplification is then repeated by an automated system for about 40 cycles until the viral cDNA can be identified by fluorescent or electrical signal [8].

RT-PCR can be carried out using either a one-step or a two-step procedure but the preferred method is one-step because it is faster-reduces exposure and bench time and it decreases pipetting errors as well as cross-contamination between the RT and real-time PCR steps [9].

Serological (antibody-based) testing, which is recently being introduced as supplemental testing, identifies antibodies developed to the virus in individuals who previously had the infection [10]. This plays a great role in unveiling the epidemiology of SARS-CoV-2 [11]. The rate and degree of mutation variability of SARS-CoV-2 and the identification of emerging viral strains for more effective vaccine development are done using viral genomic sequencing, which is a more complex diagnostic testing [5].

The role of medical laboratory science in the monitoring patients cannot be overemphasized. Many laboratory tests help in assessing the severity of disease (disease staging) as well as prognosis (assessing the risk of progression of COVID-19 towards ARDS, DIC, and/or MOF).

Commonly observed abnormalities in patients with COVID-19 are decreased values of lymphocyte and albumin as well as increased values of $\mathrm{C}$ reactive protein (CRP), lactate dehydrogenase (LDH), erythrocyte sedimentation rate (ESR), D-dimer, leukocytes, alanine aminotransferase (ALT), aspartate aminotransferase (AST), total bilirubin, cardiac troponins, creatinine, procalcitonin, and prolong prothrombin time (PT), are all of important in COVID-19 prognosis [12].

To meet up with the demands of quality healthcare service and the expectations to produce timely, reliable, and accurate results, which serve as the basis for effective, as well as efficient diagnosis, treatment, and management of COVID-19 cases, it is expedient for medical scientists to have accurate and in-depth knowledge of the epidemiology and laboratory diagnosis of COVID-19. This will bring about an impactful pandemic response by reducing the spread and mortality rate.

The purposes of this study are to determine the knowledge of COVD-19 (general knowledge and causes, symptoms, and mode of transmission) and assess the knowledge of laboratory diagnosis of SARS-CoV-2 among medical scientists.

\section{Methodology}

One hundred and thirty-one medical scientists participated in the descriptive cross-sectional survey conducted in Nigeria. The participants were recruited from the six-geopolitical zones in Nigeria. Participants were required to give informed consent to take part in the survey and they were the assurance of absolute respect, confidentiality and anonymity. 


\subsection{Survey Instrument}

The questionnaire used for this survey was adapted from the World Health Organization interim guidance document for 『laboratory testing for Coronavirus disease 2019 ([COVID-19)" in suspected human cases [8] and was designed using Google form. It was validated by face validity and has an overall internal consistency of 0.8 (Cronbach's Alpha method). Due to the lockdown in the country during the period of the data collection, the questionnaire was broadcasted by the internet and the link was sent to interested participants. The questionnaire sought information on respondents' socio-demographic, general knowledge and causes, mode of transmission, symptoms associated with COVID-19, and laboratory diagnosis of COVID-19.

The general knowledge and causes section had 5 items, the mode of transmission section had 8 items, the symptoms associated with COVID-19 section had 3 items and the knowledge of laboratory diagnosis of COVID-19 section had 7 items. Most questions were recorded on a six-point Likert scale with a few multiple-choice questions. Strongly agree and agree responses were reported as agree while strongly disagree and disagree responses were reported as agree.

\subsection{Inclusion and Exclusion Criteria}

Medical scientists from the six geopolitical zones of Nigeria were included in the study while medical scientists working in hospitals and diagnostic centres with no facilities for COVID-testing were excluded from the study.

\subsection{Data Analysis}

To ascertain the accuracy and completeness of the data obtained, the data were entered and cleaned. The 6-points Likert Scale questions were coded from 1 to 6. "Strongly disagreed" was coded as 1, "Disagree" was coded as 2 "Slightly Disagree" was coded as 3, "Slightly Agree" was coded as 4, "Agree" was coded as 5, and "Strongly Agree" was coded as 6. The maximum obtainable score for questions on the general knowledge and causes of COVID-19 was 30; the knowledge of the mode of transmission of COVID-19 was 48; the symptom associated with COVID-19 was 18, and the knowledge of laboratory diagnosis of COVID-19 was 42. The respondents' mean score for the level of general knowledge and causes of COVID-19 was 22.4 ( \pm 3.6$)$, mode of transmission of COVID-19 was $38.8( \pm 4.5)$, symptoms associated with COVID-19 was $8.4( \pm 2.0)$, and knowledge level of laboratory diagnosis of COVID-19 was $15.1( \pm 2.3)$. The respondents' scores below these mean scores were categorized as poor while scores above these mean scores were categorized as good.

Analysis was done using IBM SPSS Statistics version 25. Descriptive statistics (frequency distribution, mean $\pm \mathrm{SD}$ ) and inferential statistics (Chi-square $\left(\chi^{2}\right)$ test and multivariate linear regression model) were explored. The confidence 
level was set at $95 \%$ and the significant level at $\mathrm{p}<0.05$.

\section{Results}

\subsection{Socio-Demographic Characteristics of Subjects}

Most of the respondents were males (64.1\%), Christians (81.7\%), graduates (64.1\%) with years of work experience between 1 and 9 years (70.2\%), and the present work level between levels 1 and 5 (61.1\%) [13]. (Table 1 [13], Figure 1 and Figure 2).

\subsection{General Knowledge of COVID-19}

Most of the respondents (84.7\%) recognized the causative agent of COVID-19 to

Table 1. Socio-demographic Characteristics of Respondents; $n=$ Total Number of Respondents.

\begin{tabular}{ccc}
\hline Socio-demographic Characteristics & Frequency $(\mathbf{n}=\mathbf{1 3 1})$ & Percentage $(\mathbf{1 0 0 \% )}$ \\
\hline Age Range: & 2 & 1.5 \\
$<20$ years & 55 & 42.0 \\
$20-29$ years & 44 & 33.6 \\
$30-39$ years & 20 & 15.3 \\
$40-49$ years & 10 & 7.6 \\
50 - 59 years & & \\
Religion: & 107 & 81.6 \\
Christianity & 23 & 17.6 \\
Islam & 1 & 0.8 \\
Agnostic & & \\
Education Level: & 84 & 64.1 \\
Graduate & 39 & 29.8 \\
Post graduate & 8 & 6.1 \\
Fellowship & 131 & 100.0 \\
Total & &
\end{tabular}

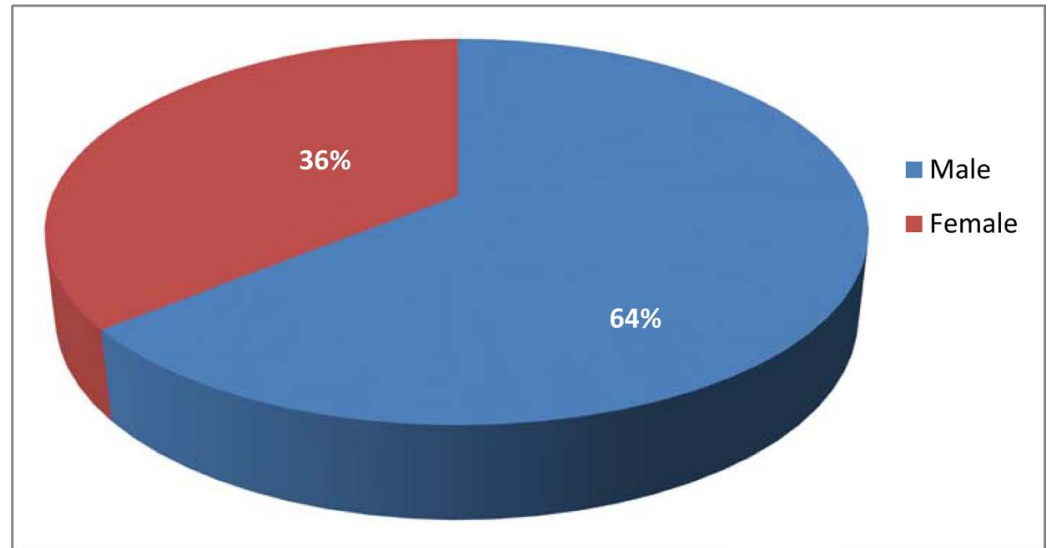

Figure 1. Gender. 
be Severe Acute Respiratory Syndrome Coronavirus 2 (SARS-CoV-2) (Figure 3) and that Coronavirus is an infectious agent (96.9\%) (Table 2). The mean score of general knowledge and causes of COVID-19 was 22.4 ( \pm 3.6$)$ with 68 (52\%) respondents scoring above the mean and were classified as having good knowledge of COVID-19 and its cause (Figure 4).

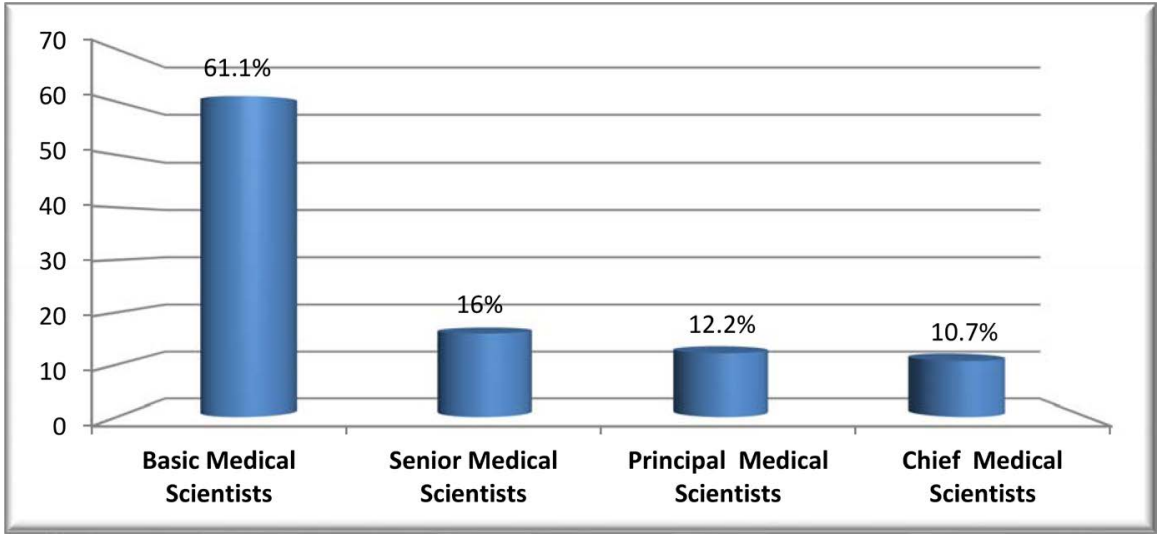

Figure 2. Work level.

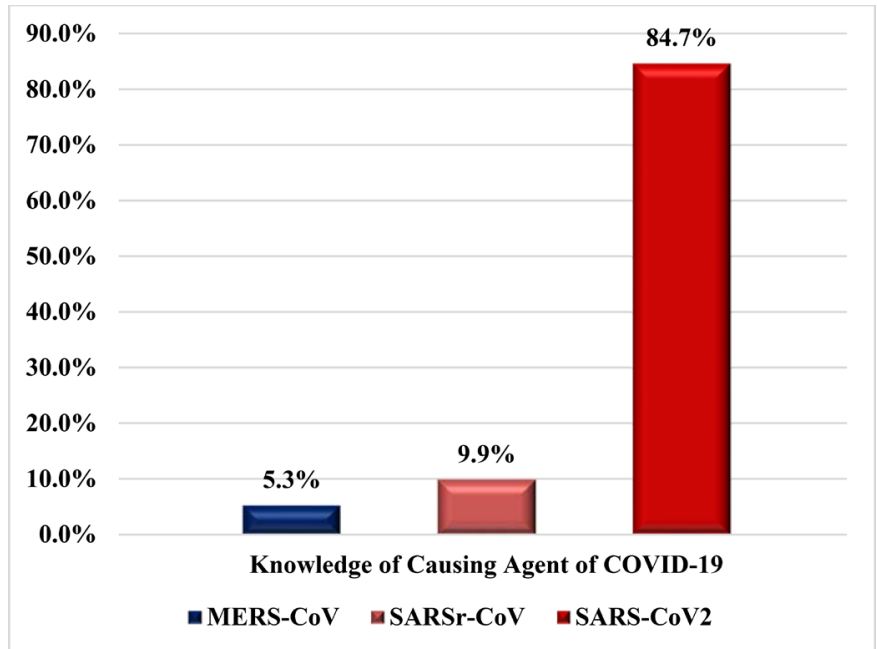

Figure 3. Respondents' Knowledge of Covid-19 causing agent.

Table 2. General Knowledge and Causes of COVID-19. $\mathrm{n}$ = Total Number of Respondents.

\begin{tabular}{|c|c|c|c|c|c|c|}
\hline & $\begin{array}{c}\text { Strongly } \\
\text { agree } \\
\text { n (\%) }\end{array}$ & $\begin{array}{l}\text { Agree } \\
\text { n (\%) }\end{array}$ & $\begin{array}{l}\text { Slightly agree } \\
\text { n (\%) }\end{array}$ & $\begin{array}{c}\text { Slightly } \\
\text { disagree } \\
\text { n (\%) }\end{array}$ & $\begin{array}{l}\text { Disagree } \\
\mathrm{n}(\%)\end{array}$ & $\begin{array}{c}\text { Strongly } \\
\text { disagree } \\
\text { n (\%) }\end{array}$ \\
\hline Coronavirus is an infectious agent & $\begin{array}{c}111 \\
(84.7)\end{array}$ & $\begin{array}{c}16 \\
(12.2)\end{array}$ & $\begin{array}{c}1 \\
(0.8)\end{array}$ & $\begin{array}{c}0 \\
(0.0)\end{array}$ & $\begin{array}{c}3 \\
(2.3)\end{array}$ & $\begin{array}{c}0 \\
(0.0)\end{array}$ \\
\hline $\begin{array}{l}\text { The Covid-19 disease is restricted to certain regions or countries of } \\
\text { the world }\end{array}$ & $\begin{array}{c}7 \\
(5.3)\end{array}$ & $\begin{array}{c}5 \\
(3.8)\end{array}$ & $\begin{array}{c}2 \\
(1.5)\end{array}$ & $\begin{array}{c}4 \\
(3.1)\end{array}$ & $\begin{array}{c}32 \\
(24.4)\end{array}$ & $\begin{array}{c}81 \\
(61.8)\end{array}$ \\
\hline $\begin{array}{l}\text { The Covid-19 disease has been found to be sensitive and prevented } \\
\text { by previous vaccination to other Coronaviruses infection }\end{array}$ & $\begin{array}{c}3 \\
(2.3)\end{array}$ & $\begin{array}{c}10 \\
(7.6)\end{array}$ & $\begin{array}{c}12 \\
(9.2)\end{array}$ & $\begin{array}{c}9 \\
(6.9)\end{array}$ & $\begin{array}{c}44 \\
(33.6)\end{array}$ & $\begin{array}{c}53 \\
(40.5)\end{array}$ \\
\hline All body fluids transmit the SARS-CoV-2 equally & $\begin{array}{c}19 \\
(14.5)\end{array}$ & $\begin{array}{c}33 \\
(25.2)\end{array}$ & $\begin{array}{c}9 \\
(6.9)\end{array}$ & $\begin{array}{c}16 \\
(12.2)\end{array}$ & $\begin{array}{c}34 \\
(26.0)\end{array}$ & $\begin{array}{c}20 \\
(15.3)\end{array}$ \\
\hline
\end{tabular}




\subsection{Knowledge of COVID-19's Mode of Transmission}

The majority of the respondents opined that Coronavirus disease (COVID-19) can be transmitted through handshaking (90.9\%), through droplets during coughing or sneezing (99.2\%) and that COVID-19 is more contagious but less severe compared to Acute respiratory syndrome SARS and middle east respiratory syndrome MERS(54.2\%) (Table 3). The mean knowledge score of the mode of transmission of COVID-19 was $38.8( \pm 4.5)$ and 69 (52.7\%) respondents were categorized as having good knowledge of COVID-19 mode of transmission as they scored above mean as seen in Figure 5.

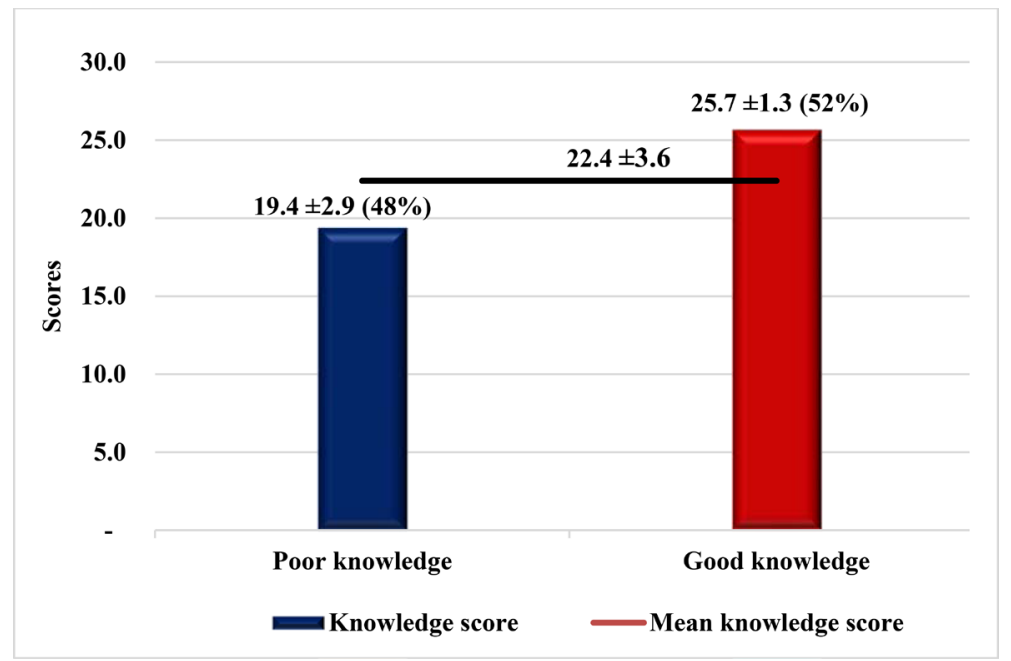

Figure 4. Knowledge Level and Mean Scores of COVID-19 and its causes.

Table 3. Knowledge of COVID-19's mode of transmission.

\begin{tabular}{|c|c|c|c|c|c|c|}
\hline & $\begin{array}{c}\text { Strongly } \\
\text { agree } \\
\text { n (\%) }\end{array}$ & $\begin{array}{l}\text { Agree } \\
\text { n (\%) }\end{array}$ & $\begin{array}{c}\text { Slightly } \\
\text { agree } \\
\text { n (\%) }\end{array}$ & $\begin{array}{c}\text { Slightly } \\
\text { disagree } \\
\mathrm{n}(\%)\end{array}$ & $\begin{array}{c}\text { Disagree } \\
\text { n (\%) }\end{array}$ & $\begin{array}{c}\text { Strongly } \\
\text { disagree } \\
\mathrm{n}(\%)\end{array}$ \\
\hline Coronavirus disease (COVID-19) can be transmitted through handshaking & $\begin{array}{c}75 \\
(57.3)\end{array}$ & $\begin{array}{c}44 \\
(33.6)\end{array}$ & $\begin{array}{c}5 \\
(3.8)\end{array}$ & $\begin{array}{c}0 \\
(0.0)\end{array}$ & $\begin{array}{c}4 \\
(3.1)\end{array}$ & $\begin{array}{c}3 \\
(2.3)\end{array}$ \\
\hline $\begin{array}{l}\text { Coronavirus disease (COVID-19) can be transmitted through mosquito and/or } \\
\text { other insects bite }\end{array}$ & $\begin{array}{c}2 \\
(1.5)\end{array}$ & $\begin{array}{c}7 \\
(5.3)\end{array}$ & $\begin{array}{c}7 \\
(5.3)\end{array}$ & $\begin{array}{c}0 \\
(0.0)\end{array}$ & $\begin{array}{c}49 \\
(37.4)\end{array}$ & $\begin{array}{c}66 \\
(50.4)\end{array}$ \\
\hline $\begin{array}{l}\text { Coronavirus disease (COVID-19) can be transmitted through blood transfusion } \\
\text { or contaminated needles }\end{array}$ & $\begin{array}{c}38 \\
(29.0)\end{array}$ & $\begin{array}{c}33 \\
(25.2)\end{array}$ & $\begin{array}{c}10 \\
(7.6)\end{array}$ & $\begin{array}{c}6 \\
(4.6)\end{array}$ & $\begin{array}{c}23 \\
(17.6)\end{array}$ & $\begin{array}{c}21 \\
(16.0)\end{array}$ \\
\hline $\begin{array}{l}\text { Coronavirus disease (COVID-19) can be transmitted through improper } \\
\text { handling of corpses who died from the disease }\end{array}$ & $\begin{array}{c}72 \\
(55.0)\end{array}$ & $\begin{array}{c}35 \\
(26.7)\end{array}$ & $\begin{array}{c}10 \\
(7.6)\end{array}$ & $\begin{array}{c}3 \\
(2.3)\end{array}$ & $\begin{array}{c}8 \\
(6.1)\end{array}$ & $\begin{array}{c}3 \\
(2.3)\end{array}$ \\
\hline $\begin{array}{l}\text { The risk of human-human transmission of SARS-CoV- } 2 \text { can occur in both } \\
\text { symptomatic and non-symptomatic phases }\end{array}$ & $\begin{array}{c}91 \\
(69.5)\end{array}$ & $\begin{array}{c}36 \\
(27.5)\end{array}$ & $\begin{array}{c}4 \\
(3.1)\end{array}$ & $\begin{array}{c}0 \\
(0.0)\end{array}$ & $\begin{array}{c}0 \\
(0.0)\end{array}$ & $\begin{array}{c}0 \\
(0.0)\end{array}$ \\
\hline Coronavirus disease (COVID-19) is airborne & $\begin{array}{c}27 \\
(20.6)\end{array}$ & $\begin{array}{c}38 \\
(29.0)\end{array}$ & $\begin{array}{c}24 \\
(18.3)\end{array}$ & $\begin{array}{c}8 \\
(6.1)\end{array}$ & $\begin{array}{c}25 \\
(19.1)\end{array}$ & $\begin{array}{c}9 \\
(6.9)\end{array}$ \\
\hline $\begin{array}{l}\text { Coronavirus disease (COVID-19) can be transmitted through droplets during } \\
\text { coughing or sneezing }\end{array}$ & $\begin{array}{c}113 \\
(86.2)\end{array}$ & $\begin{array}{c}17 \\
(13.0)\end{array}$ & $\begin{array}{c}1 \\
(0.8)\end{array}$ & $\begin{array}{c}0 \\
(0.0)\end{array}$ & $\begin{array}{c}0 \\
(0.0)\end{array}$ & $\begin{array}{c}0 \\
(0.0)\end{array}$ \\
\hline $\begin{array}{l}\text { COVID-19 is more contagious but less severe compared to Acute respiratory } \\
\text { syndrome SARS and middle east respiratory syndrome MERS. }\end{array}$ & $\begin{array}{c}30 \\
(22.9)\end{array}$ & $\begin{array}{c}41 \\
(31.3)\end{array}$ & $\begin{array}{c}11 \\
(8.4)\end{array}$ & $\begin{array}{c}4 \\
(3.1)\end{array}$ & $\begin{array}{c}37 \\
(28.2)\end{array}$ & $\begin{array}{c}8 \\
(6.1)\end{array}$ \\
\hline
\end{tabular}




\subsection{Knowledge of Symptoms of COVID-19}

One hundred and eight (84.4\%) respondents confirmed that the most typical clinical symptom in laboratory-confirmed cases of COVID-19 is "dry cough" (Table 4(a)). Most of the respondents (71\%) agreed that according to the World Health Organization (WHO), the percentage of patients with severe SARS-CoV-2 infection who experience mild symptoms are higher than the percentage of those who are critically ill (Table 4(b)). The mean score for knowledge of COVID-19 symptoms was $8.4( \pm 2.0)$. Seventy-one $(54.2 \%)$ respondents scored above mean

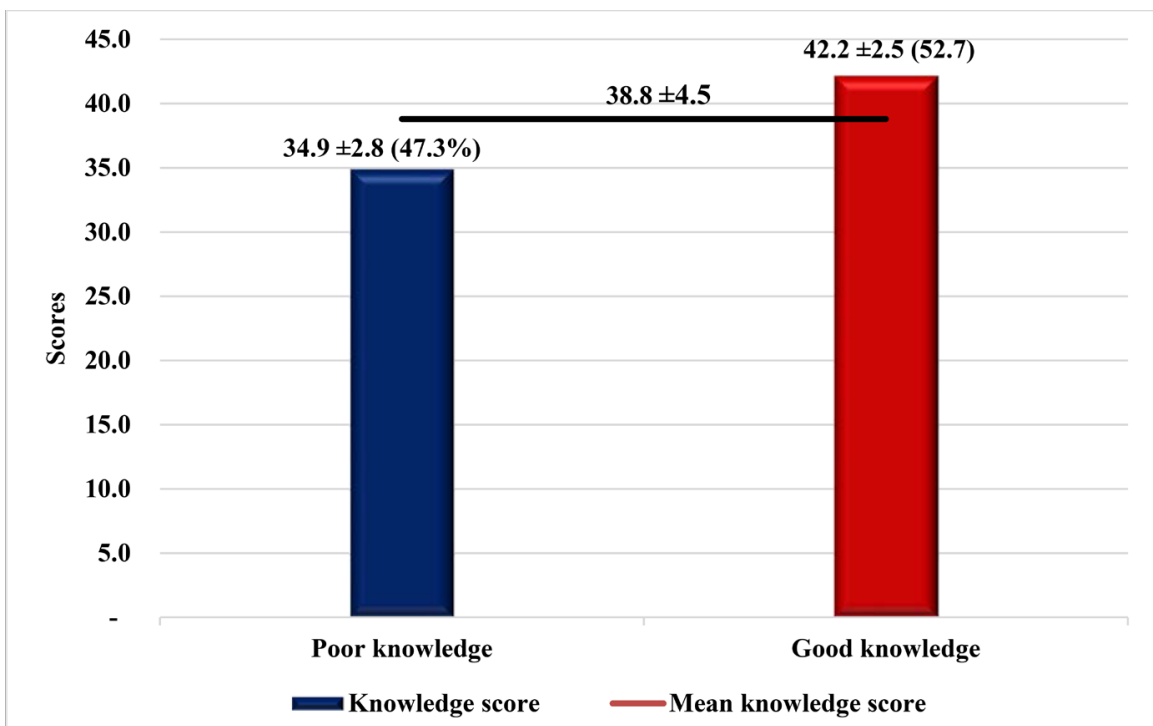

Figure 5. Knowledge Level and Mean Scores of mode of transmission of Coronavirus

Table 4. (a) The most TYPICAL clinical symptoms in laboratory-confirmed cases of COVID-19; (b) Knowledge of COVID-19 symptoms.

(a)

\begin{tabular}{ccc}
\hline & Frequency $(\mathrm{n}=131)$ & Percentage $(100 \%)$ \\
\hline Diarrhea and Vomiting & 18 & 14.1 \\
Dry Cough & 108 & 84.4 \\
Fatigue & 48 & 37.5 \\
Fever & 79 & 61.7 \\
Phlegm Production & 22 & 17.2 \\
\hline
\end{tabular}

(b)

\begin{tabular}{|c|c|c|c|c|c|c|}
\hline & $\begin{array}{l}\text { Strongly } \\
\text { agree } \\
\text { n (\%) }\end{array}$ & $\begin{array}{l}\text { Agree } \\
\text { n (\%) }\end{array}$ & $\begin{array}{l}\text { Slightly } \\
\text { agree } \\
\text { n (\%) }\end{array}$ & $\begin{array}{l}\text { Slightly } \\
\text { disagree } \\
\mathrm{n}(\%)\end{array}$ & $\begin{array}{c}\text { Disagree } \\
\text { n (\%) }\end{array}$ & $\begin{array}{c}\text { Strongly } \\
\text { disagree } \\
\mathrm{n}(\%)\end{array}$ \\
\hline Symptoms appear between 18 - 20 days after being infected & $\begin{array}{c}16 \\
(12.2)\end{array}$ & $\begin{array}{c}29 \\
(22.1)\end{array}$ & $\begin{array}{c}17 \\
(13.0)\end{array}$ & $\begin{array}{c}7 \\
(5.3)\end{array}$ & $\begin{array}{c}34 \\
(26.0)\end{array}$ & $\begin{array}{c}28 \\
(21.4)\end{array}$ \\
\hline $\begin{array}{l}\text { According to WHO, the percentage of patients with severe SARS-CoV-2 } \\
\text { infection who experience mild symptoms are higher than the percentage of } \\
\text { those who are critically ill }\end{array}$ & $\begin{array}{c}39 \\
(29.8)\end{array}$ & $\begin{array}{c}54 \\
(41.2)\end{array}$ & $\begin{array}{c}16 \\
(12.2)\end{array}$ & $\begin{array}{c}3 \\
(2.3)\end{array}$ & $\begin{array}{c}15 \\
(11.5)\end{array}$ & $\begin{array}{c}4 \\
(3.1)\end{array}$ \\
\hline
\end{tabular}


and were classified as having good knowledge of symptoms of COVID-19 as seen in Figure 6.

\subsection{Knowledge Level of Laboratory Diagnosis of SARS-CoV-2}

It was shown in Table 5 that the majority of respondents agreed that the collected specimen must be put into a viral transport medium (96.1\%) and that diffuse alveolar damage characterized by the presence of cellular fibromyxoid exudates, desquamation of pneumocytes, and hyaline membrane formation is diagnostic pulmonary histology in COVID-19 (75.6\%).

However, only a few study participants knew the hallmark of laboratory diagnosis of COVID-19 (Lymphopenia 37.4\%, Increase LDH 20.69\% and Prolong PT 13.7\%) and Coronavirus detection steps in the right order (45\%).

\subsection{Relationship between General Knowledge of COVID-19, Knowledge of Laboratory Diagnosis of SARS-CoV-2, and Respondents' Demographics.}

The overall knowledge level of COVID-19 (causes, mode of transmission, symptoms and knowledge laboratory diagnosis of SARS-CoV-2) was significantly associated with the respondents' gender, $\left(\chi^{2}=4.173 ; \mathrm{p}=0.041\right)$.

Besides, respondents who were between ages 40 and 49 years had the highest mean knowledge score of $75.6( \pm 7.9)$ over other age groups (Table 6$)$ and there was a significant mean difference in the knowledge scores among the age groups $(\mathrm{F}$-ratio $=2.729 ; \mathrm{p}=0.032)$. Principal medical scientists had the highest mean knowledge score of $76.5( \pm 6.9)$ over other age groups and there was a significant mean difference in knowledge scores in relationship with the respondents' level at work (F-ratio $=3.552 ; \mathrm{p}=0.016)$. The respondents who had post-graduate education recorded a high mean knowledge score of $73.0( \pm 5.7)$ over the other educational qualifications, but there was no significant mean difference in

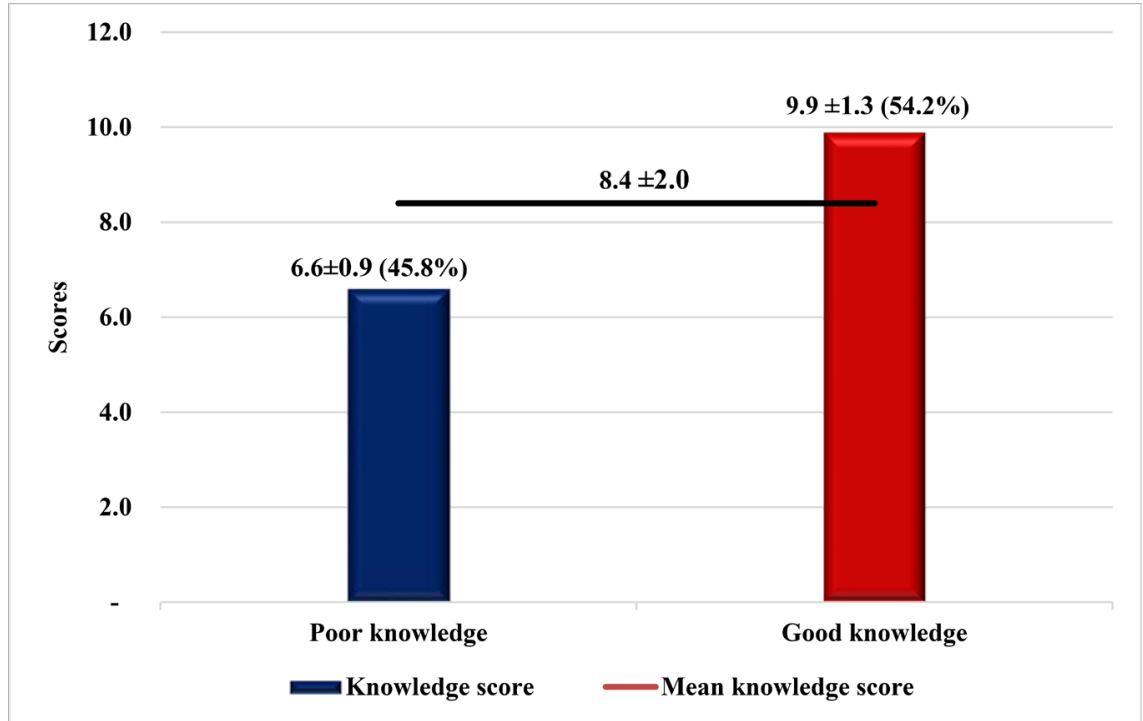

Figure 6. Knowledge level and Mean Scores of COVID-19 Symptoms. 
Table 5. Knowledge of laboratory diagnosis of SARS-CoV-2.

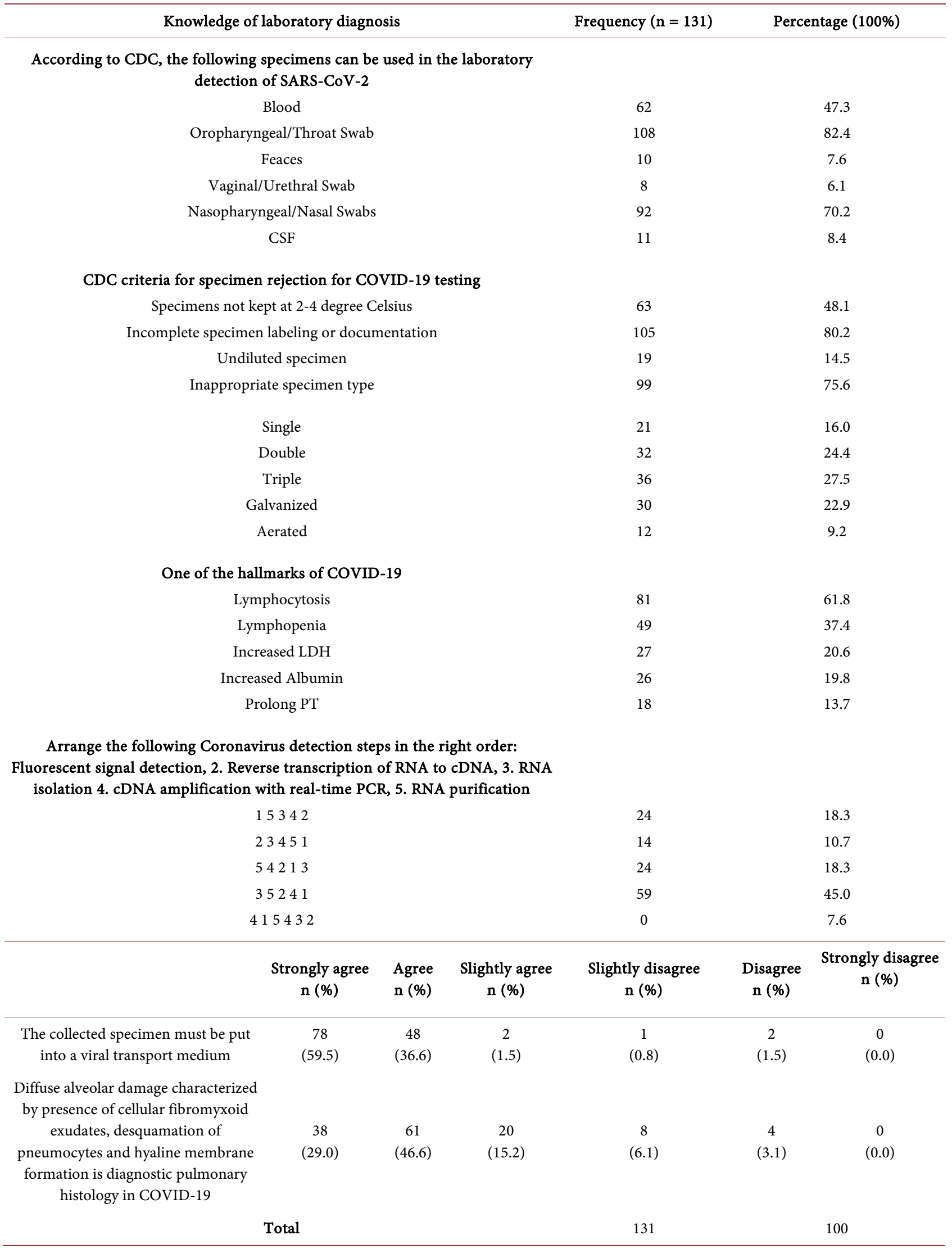


Table 6. General Knowledge level of COVID-19 and knowledge of laboratory diagnosis of SARS-CoV-2 in relation to respondents' demographics.

\begin{tabular}{|c|c|c|c|c|c|}
\hline \multirow{2}{*}{ Demographic data } & \multicolumn{2}{|c|}{ Knowledge level } & \multirow{2}{*}{$\begin{array}{l}\text { Mean knowledge scores } \\
\text { Mean } \pm \text { S.D. }\end{array}$} & \multirow{2}{*}{$x^{2}$} & \multirow{2}{*}{$\begin{array}{l}\text { Significant mean } \\
\text { difference F-ratio }\end{array}$} \\
\hline & Poor n (\%) & Good n (\%) & & & \\
\hline \multicolumn{6}{|l|}{ Age (in grouped years): } \\
\hline$<20$ years & $1(1.6)$ & $1(1.5)$ & $73.0 \pm 2.8$ & \multirow{5}{*}{$\begin{array}{c}7.566 \\
p=0.109\end{array}$} & \multirow{5}{*}{$\begin{array}{c}2.729 \\
p=0.032\end{array}$} \\
\hline $20-29$ years & $30(47.6)$ & $25(36.8)$ & $70.6 \pm 5.4$ & & \\
\hline 30 - 39 years & $23(36.5)$ & $21(30.9)$ & $71.2 \pm 5.9$ & & \\
\hline 40 - 49 years & $4(6.3)$ & $16(23.5)$ & $75.6 \pm 7.9$ & & \\
\hline 50 - 59 years & $5(7.9)$ & $5(7.4)$ & $73.9 \pm 9.3$ & & \\
\hline \multicolumn{6}{|l|}{ Gender: } \\
\hline Male & $46(73.0)$ & $38(55.9)$ & $71.4 \pm 6.8$ & \multirow{2}{*}{$\begin{array}{c}4.173 \\
\mathrm{p}=0.041\end{array}$} & \multirow{2}{*}{$\begin{array}{c}1.111^{\star} \\
\mathrm{p}=0.269\end{array}$} \\
\hline Female & $17(27.0)$ & $30(44.1)$ & $72.7 \pm 5.9$ & & \\
\hline \multicolumn{6}{|l|}{ Religion: } \\
\hline Christianity & $52(82.5)$ & $55(80.9)$ & $71.7 \pm 6.8$ & 1.286 & 0.158 \\
\hline Islam & $10(15.9)$ & $13(19.1)$ & $72.5 \pm 5.4$ & \multirow[t]{2}{*}{$\mathrm{p}=0.526$} & \multirow[t]{2}{*}{$\mathrm{p}=0.854$} \\
\hline Agnostic & $1(1.6)$ & $0(0.0)$ & $71.0 \pm 0.0$ & & \\
\hline \multicolumn{6}{|l|}{ Highest Education: } \\
\hline Graduate & $42(66.7)$ & $42(61.8)$ & $71.3 \pm 6.4$ & 1.568 & 0.915 \\
\hline Post graduate & $16(25.4)$ & $23(33.8)$ & $73.0 \pm 5.7$ & \multirow[t]{2}{*}{$\mathrm{p}=0.457$} & \multirow[t]{2}{*}{$\mathrm{p}=0.403$} \\
\hline Fellowship & $5(7.9)$ & $3(4.4)$ & $71.9 \pm 10.3$ & & \\
\hline \multicolumn{6}{|l|}{ Level at work: } \\
\hline Basic medical scientists & $41(65.1)$ & $39(57.4)$ & $71.24 \pm 5.7$ & \multirow{4}{*}{$\begin{array}{c}7.310 \\
p=0.063\end{array}$} & \multirow{4}{*}{$\begin{array}{c}3.552 \\
p=0.016\end{array}$} \\
\hline Senior medical scientists & $10(15.9)$ & $11(16.2)$ & $71.8 \pm 7.5$ & & \\
\hline Principal medical scientists & $3(4.8)$ & $13(19.1)$ & $76.5 \pm 6.9$ & & \\
\hline Chief medical scientists & $9(14.3)$ & $5(7.4)$ & $70.0 \pm 6.9$ & & \\
\hline
\end{tabular}

*Student's t-test as Gender was only of 2 categories.

knowledge score in education.

\section{Discussion}

As part of a multidisciplinary medical team, medical scientists play a great role in the detection, management, and containment of the spread of SARS-CoV-2 infection. The quality of care provided by the medical scientists depends on the level of the general knowledge and knowledge of diagnosis of SARS-CoV-2 they possess. According to a study in Zambia, the majority of the participating medical laboratory professionals (84.1\%) had good knowledge of COVID-19 [14]. This finding is in tandem with the discovery in this study as more than half of the respondents had good general knowledge and causes (52\%), mode of transmission (52.7\%), and symptoms (54.2\%) of COVID-19. However, the result of this study contradicts the findings conducted globally among the health care workers where most of the respondents had poor knowledge of transmission 
(61.0\%) and symptoms onset (63.6\%) of COVID-19 [15]. It is essential to identify and fill gaps in the knowledge of COVID-19 among medical scientists while fortifying and reinforcing already established knowledge to sustain efficient and effective laboratory pandemic response.

In addition to the general knowledge of COVID-19, having sufficient knowledge of laboratory diagnosis of COVID-19 is very critical and fundamental to the management of the Coronavirus disease pandemic. It was a shocking discovery that the majority of the medical scientist who participated in this study had inadequate knowledge about Coronavirus detection steps and the hallmark of laboratory diagnosis of COVID-19. Meanwhile, the World Health Organization (WHO) clearly stated that only well-trained medical scientists may carry out COVID-19 testing. This calls for an urgent response to train and re-train medical scientists who are involved in the covid-19 testing in Nigeria, so as not to jeopardize the safety of the people as well as the efforts to contain the spread of SARS-CoV-2 infection.

Furthermore, in this study, age $(\mathrm{F}$-ratio $=2.729 \mathrm{p}=0.032)$, gender $\left(\chi^{2}=4.173\right.$; $\mathrm{p}=0.041)$ and work level $(\mathrm{F}$-ratio $=3.552, \mathrm{p}=0.016)$ have significant effects on the knowledge of COVID-19 and knowledge of laboratory diagnosis of SARS-CoV-2 among the study participants. This is in agreement with the finding in a study in China to understand the knowledge, attitudes, and practices towards COVID-19 where it was discovered that there was a significant difference in the COVID-19 knowledge level between respondents' gender [16]. This result is also consistent with a study by Alrubaiee et al. where there was a significant association between the respondents' preventive behaviour towards COVID-19 and their gender [17]. However, these findings are incongruence with the finding by Nemati et al. in which there was no significant correlation between knowledge of COVID-19 and work experience [18]. This striking difference may be due to the recent pressure on the Nigerian health system due to the COVID-19 pandemic to improve the efficiency, efficacy as well as the capacities of medical laboratory systems. The bulk of these responsibilities are saddled by the leaders in the profession and this automatically confers the need to be more informed to be able to handle the situation more proficiently.

\section{Limitations}

The participants' responses were given online based on the reliable reports of the real-time laboratory experiences. These reports may be liable to recall bias. Also generalization the study findings may be difficult due to the potential for sample clustering as well as the limited number of study participants.

\section{Conclusion}

This study revealed that even though the majority of the respondents had a good general knowledge of Covid-19, there was, however, a big knowledge gap in the diagnosis of COVID-19 among the participating medical scientists. This calls for 
urgent action to enhance the development of relevant training and continuous professional development programs to improve the knowledge of COVID-19 diagnosis among medical scientists as well as to incorporate gender and level-based delivery of such educational training. This may improve uptake of knowledge and eventually may boost the reliability and relevance of laboratory results in the COVID-19 pandemic response.

\section{Ethics Approval and Consent to Participate}

Ethics approval was waived for this study. The study participants gave informed consent to participate in the survey and they were assured of absolute respect, confidentiality and anonymity.

\section{Consent for Publication}

The study participants gave informed consent for their responses to be published.

\section{Availability of Data and Materials}

The datasets supporting the conclusions of this article are included within the article.

\section{Funding}

This research received no specific grant from any funding agency in the public, commercial, or not-for-profit sectors.

\section{Acknowledgments}

The authors thank Mr. Kayode Olaniyan for his expertise support during the data analysis of this study. Our heartfelt gratitude also goes out to Associate Professor Akin Omisore for his great assistance during the study period.

\section{Conflicts of Interest}

The authors declare no conflicts of interest regarding the publication of this paper.

\section{References}

[1] Kapata, N., Ihekweazu, C., Ntoumi, F., Raji, T., Chanda-Kapata, P., Mwaba, P., et al. (2020) Is Africa Prepared for Tackling the COVID-19 (SARS-CoV-2) Epidemic? Lessons from Past Outbreaks, Ongoing Pan-African Public Health Efforts, and Implications for the Future. International Journal of Infectious Diseases, 93, 233-236. https://doi.org/10.1016/j.ijid.2020.02.049

[2] Nigeria Centre for Disease Control (2021). https://ncdc.gov.ng/news/227/first-case-of-corona-virus-disease-confirmed-in-nige $\underline{\text { ria }}$

[3] Mattiuzzi, C. and Lippi, G. (2020) Which Lessons Shall We Learn from the 2019 Novel Coronavirus Outbreak? Annals of Translational Medicine, 8, 48. https://doi.org/10.21037/atm.2020.02.06

[4] Guo, G., Ye, L., Pan, K., Chen, Y., Xing, D., Yan, K., et al. (2020) New Insights of 
Emerging SARS-CoV-2: Epidemiology, Etiology, Clinical Features, Clinical Treatment, and Prevention. Frontiers in Cell and Developmental Biology, 8, 410. https://doi.org/10.3389/fcell.2020.00410

[5] Yu, I., Li, Y., Wong, T., Tam, W., Chan, A., Lee, J., et al. (2004) Evidence of Airborne Transmission of the Severe Acute Respiratory Syndrome Virus. New England Journal of Medicine, 350, 1731-1739. https://doi.org/10.1056/NEJMoa032867

[6] Huang, C., Wang, Y., Li, X., Ren, L., Zhao, J., Hu, Y., et al. (2020) Clinical Features of Patients Infected with 2019 Novel Coronavirus in Wuhan, China. The Lancet, 395, 497-506. https://doi.org/10.1016/S0140-6736(20)30183-5

[7] Tang, N., Li, D., Wang, X. and Sun, Z. (2020) Abnormal Coagulation Parameters Are Associated with Poor Prognosis in Patients with Novel Coronavirus Pneumonia. Journal of Thrombosis and Haemostasis, 18, 844-847.

https://doi.org/10.1111/jth.14768

[8] World Health Organization (2020)ґ Laboratory Testing for Coronavirus Disease 2019 ([COVID-19)队 in Suspected Human Cases: Interim Guidance. https://apps.who.int/iris/handle/10665/331329

[9] VanGuilder, H., Vrana, K. and Freeman, W. (2008) Twenty-Five Years of Quantitative PCR for Gene Expression Analysis. BioTechniques, 44, 619-626. https://doi.org/10.2144/000112776

[10] U.S. Department of Health and Human Service, Center for Disease Control and Prevention Guidelines for Safe Work Practices in Human and Animal Medical Diagnostic Laboratories (2012) Recommendations of a CDC-Convened, Biosafety Blue Ribbon Panel. Morbidity and Mortality Weekly Report (MMWR) Supplement, 61, 7-37.

[11] Li, C., Zhao, C., Bao, J., Tang, B., Wang, Y. and Gu, B. (2020) Laboratory Diagnosis of Coronavirus Disease-2019 (COVID-19). Clinica Chimica Acta, 510, 35-46. https://doi.org/10.1016/j.cca.2020.06.045

[12] Hanif, M., Haider, M., Xi, Q., Ali, M. and Ahmed, M. (2020) A Review of the Risk Factors Associated with Poor Outcomes in Patients with Coronavirus Disease 2019. Cureus, 12, e10350. https://doi.org/10.7759/cureus.10350

[13] LekanAgunbiade, T.T. and Agunbiade, O.I. (2021) Laboratory Diagnosis and Management of Covid-19 Cases: Creating a Safe Environment for Testing. https://www.researchsquare.com/article/rs-191071/v1 https://doi.org/10.21203/rs.3.rs-191071/v1

[14] Chawe, A., Mfune, R., Syapiila, P., Zimba, S., Vlahakis, P., Mwale, S., et al. (2021) Knowledge, Attitude and Practices of COVID-19 among Medical Laboratory Professionals in Zambia. African Journal of Laboratory Medicine, 10, a1403. https://doi.org/10.4102/ajlm.v10i1.1403

[15] Bhagavathula, A., Aldhaleei, W., Rahmani, J., Mahabadi, M. and Bandari, D. (2020) Knowledge and Perceptions of COVID-19 among Health Care Workers: Cross-Sectional Study. JMIR Public Health Surveillance, 6, e19160. https://doi.org/10.2196/19160

[16] Yue, S., Zhang, J., Cao, M. and Chen, B. (2020) Knowledge, Attitudes and Practices of COVID-19 among Urban and Rural Residents in China: A Cross-Sectional Study. Journal of Community Health, 46, 286-291. https://doi.org/10.1007/s10900-020-00877-x

[17] Alrubaiee, G.G., Al-Qalah, T.A.H. and Al-Aawar, M.S.A. (2020) Knowledge, Attitudes, Anxiety, and Preventive Behaviours towards COVID-19 among Health Care Providers in Yemen: An Online Cross-Sectional Survey. BMC Public Health, 20, 1541. 
https://doi.org/10.1186/s12889-020-09644-y

[18] Nemati, M., Ebrahimi, B. and Nemati, F. (2020) Assessment of Iranian Nurses' Knowledge and Anxiety toward COVID-19 during the Current Outbreak in Iran. Archive of Clinical Infectious Disease, 15, e102848.

https://doi.org/10.5812/archcid.102848 